\title{
Effectiveness of Medical Management in Spontaneous Expulsion of Lower Ureteral Calculi: A Prospective Study
}

\author{
Azher Mushtaq*, Sheikh Imran Farooq, Malik Suhail Ahmad, Fahad ul Islam Mir, \\ Yassar Arafat \\ Government Medical College, Srinagar, India \\ Email: *azharmushtaq82@gmail.com
}

Received 28 May 2016; accepted 22 July 2016; published 25 July 2016

Copyright (C) 2016 by authors and Scientific Research Publishing Inc.

This work is licensed under the Creative Commons Attribution International License (CC BY). http://creativecommons.org/licenses/by/4.0/

(c) $\underset{\mathrm{EY}}{\mathrm{E}}$ Open Access

\begin{abstract}
Purpose: We evaluated the efficacy of combined drug therapy with alpha1-adrenergic antagonist tamsulosin and corticosteroid deflazocort for conservative expulsive therapy in patients with lower ureteric calculi. Materials and Methods: A total of 100 consecutive symptomatic patients with stones located in the Lower ureter were selected for the study who received oral tamsulosin $0.4 \mathrm{mg}$ daily for 4 weeks and deflazocort $30 \mathrm{mg}$ daily for 10 days and diclofenac IM/Oral on demand. Ultrasound follow-up and medical visits and X ray KUB were performed weekly for 4 weeks. Stone passage rate and time, pain episodes and endoscopical intervention were evaluated. Results: The stone expulsion rate was $87.8 \%$. Mean stone size was $6.5 \pm 2.14 \mathrm{~mm}$. Mean expulsion time was $8 \pm 1.84$ days. Mean pain episodes were $1.50 \pm 0.87$ days. 11 patients needed intervention for stone retrieval. There was no statistically significant difference between the expulsion rates of right and left ureteral stones $(P$ value $=0.31)$. Conclusions: Medical therapy with a combination of $\alpha_{1}$ adrenergic blocker and corticosteroid achieve good stone expulsion rates, lower pain episodes and should be considered in all patients with lower ureteral stones of size less than $10 \mathrm{~mm}$ who are not having any contraindications for medical therapy.
\end{abstract}

\section{Keywords}

Tamsulosin, KUB, Stone, Ureteric Calculi

\section{Introduction}

Urolithiasis affects $5 \%-15 \%$ of the population worldwide [1]. Although as the literature reports the disease

${ }^{*}$ Corresponding author.

How to cite this paper: Mushtaq, A., Farooq, S.I., Ahmad, M.S., Mir, F.I. and Arafat, Y. (2016) Effectiveness of Medical Management in Spontaneous Expulsion of Lower Ureteral Calculi: A Prospective Study. Surgical Science, 7, $321-324$.

http://dx.doi.org/10.4236/ss.2016.77046 
frequency tends to increase in the western countries but a significant burden of the disease also exists in this part of the world. The stones may be present anywhere along the urinary tract; the pelvicalyceal system or in the ureter which may be proximal ureter or distal ureter, with the point of division being the narrow part of the ureter over the iliac vessels. Ureteral calculi most commonly present with symptoms of acute renal colic. If urgent intervention is not needed, the patient and clinician must decide whether to intervene or proceed with expectant management. The likelihood of spontaneous passage decreases as stone size increases [2]. An extensive meta-analysis found that most ureteral calculi $<5 \mathrm{~mm}$ in diameter will pass through the urinary tract spontaneously [3]. Spontaneous passage usually occurs within four weeks after the onset of symptoms [3]. Several factors are thought to influence the spontaneous passage of ureteral stones, such as stone size, configuration and location, smooth muscle spasm, submucosal edema, and anatomy [4] [5]. To facilitate the spontaneous passage of these ureteral calculi, many pharmacological agents like adrenergic blockers, calcium channel blockers, prostaglandin synthesis inhibitors, glyceryl trinitrate and steroid treatment to relieve edema are being used with varying efficacy rates [6]-[8]. Currently $\alpha 1$-adrenergic receptor antagonists represent the treatment of choice for lower urinary tract symptoms, as shown in many randomized controlled trials as well as in several studies [6] [9]-[11]. They act by inhibiting the basal tone, peristaltic wave frequency and the ureteral contraction in the intramural parts of the ureter. The duration of the stone expulsion rate with a medical therapy depends not only on the effectiveness drug itself but also on the patient compliance with the medicine and their follow up particularly in a socioeconomically poor country like India. We therefore studied the effectiveness of combination pharmacological therapy in spontaneous stone expulsion in cases of distal ureteral calculi in a tertiary care hospital in Kashmir.

\section{Materials and Methods}

It was a prospective hospital based study which included patients presenting to the emergency and OPD department of a tertiary care hospital in Kashmir with urinary symptoms and were diagnosed as having a ureteric calculus with a radiographic evidence of stone in the distal ureter. A total of 100 patients above age of 18 years, all having radiographic evidence of stone in the lower ureter were included in the study. Biochemical and hematological evaluation of all patients was obtained before the treatment and a complete urine analyses was performed before, during and after treatment. All patients were evaluated with X-rays of the kidneys, ureters, bladder and urinary system ultrasonography before the treatment. Stone size was recorded for each patient before starting treatment. Patients having radiolucenct stones, severe hydronephrosis, diabetes, ulcer disease and patients who had had distal ureter surgery were excluded from the study.

The patients were then started on a combination drug therapy with an $\alpha$ - adrenergic blocker (Tamsulosin 0.4 mg) daily continued for 1 month; a corticosteroid (Deflazocort $30 \mathrm{mg}$ ) daily for 10 days and an analgesic (diclofenac oral/IV) given on demand. All patients were advised to consume atleast 2 litres of water daily. The patients were examined weekly with ultrasonography and KUB for 4 weeks and the stone expulsion rate and time, pain episodes during follow up period, total diclofenac dosage and the need for any intervention was noted.

\section{Results and Observations}

The demographic distribution of the patients in our study is summarized in Table 1.

Majority of patients in this study were males with male to female ratio being 2.3:1. The average stone size is $6.5 \mathrm{~mm}$.

The results of pharmacotherapy in our study are summarized in Table 2 and Figure 1.

Mean duration of stone expulsion was $8 \pm 0.87$ days (range from 1 to 10 days). 10 patients in this study lost follow up. So the stone expulsion rate in the study came out to be $87.8 \%$. There was no difference in the stone

\begin{tabular}{|c|c|}
\hline Mean Age (in years) \pm SD & $38.42 \pm 8.20$ \\
\hline Sex Male/Female & $70 / 30$ \\
\hline Mean stone size (in $\mathrm{mm}) \pm \mathrm{SD}$ & $6.50 \pm 2.14$ \\
\hline Stone localization Rt./Lt. & $60 / 40$ \\
\hline
\end{tabular}




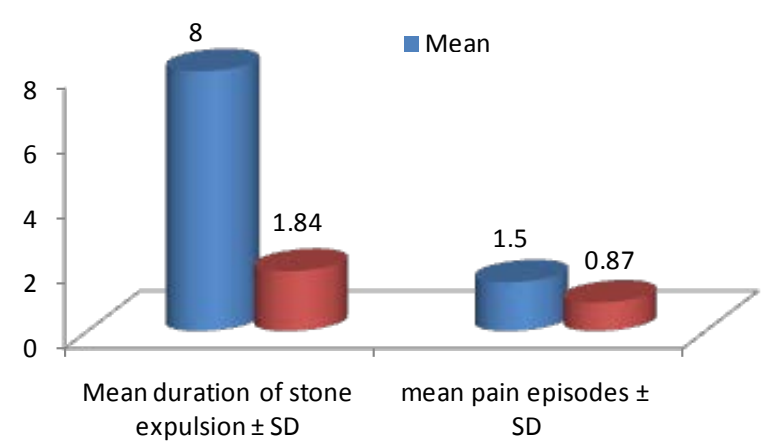

Figure 1. Chart showing results of pharmacotherapy.

Table 2. Results of pharmacotherapy.

\begin{tabular}{cc}
\hline Stone expulsion rate & $87.8 \%$ \\
\hline Mean duration of stone expulsion(in days) \pm SD & $8 \pm 1.84$ \\
Mean pain episodes(in days) \pm SD & $1.50 \pm 0.87$ \\
\hline
\end{tabular}

expulsion rates between right and left ureteric stones.11 patients in this study were not stone free after 4 weeks of follow up and pharmacotherapy and were successfully treated by ESWL and ureteroscopic retrieval after 4 weeks of medical management.

\section{Discussion}

Despite the introduction of minimally invasive therapies for lower ureteric stones like ESWL and flexible ureteroscopic retrieval, still the role of watchful waiting and pharmacotherapy for lower ureteric stones cannot be dismissed. Though being scar free, these procedures lend a lot of inconvenience to the patients, are not free of risks and are quite expensive. Even in cases of complete urinary obstruction, it takes at least 3 to 4 weeks for the signs of kidney injury to appear, therefore the spontaneous passage of the stones can be waited on for at least 4 weeks [12].

In 1970 Malin et al. demonstrated the presence of $\alpha$ and $\beta$-adrenergic receptors in human ureter, and $\alpha$-adrenergic receptors in animal ureter [13]. The stimulation effect of ureteral contraction by $\alpha$-adrenergic agonists is dose dependent and increases the frequency of ureteric peristalsis and the tone of muscles causing ureteral obstruction thus decreasing the ureteral flow. The specific antagonists of the $\alpha$-adrenergic receptors decrease the amplitude and the frequency of ureteral peristalsis, as a result the intraureteral pressure decreases and the urine transport increases.

Dellabella et al. reported the ratio of the spontaneous passage of the stones with tamsulosin corticosteroid combination as $100 \%$ in their series of 30 patients and they have demonstrated that analgesic dosage decreases with thepain frequency [6]. In another study Porpiglia et al. stressed that tamsulosin reduced expulsion time 9.7 Tekin et al. reported that in their study of 36 patients the ratio of spontaneous passage of the stones with tamsulosin alone was $77 \%$ [14].

In our study, we noted a stone expulsion rate of $87.8 \%$ with tamsulosin and corticosteroid combination with mean pain episodes of $1.50 \pm 0.87$ days. The slightly lower expulsion rates in our study are probably because of the reduced adherence to the continuous medical therapy once the patient became pain free after a few days of treatment. In our study, the largest stone expelled with medical therapy was an $8.0 \mathrm{~mm}$ stone in a young female of 32 years of age. 10 patients in our study lost follow up while as in 11 patients intervention was needed for stone removal. The mean stone size in our study was $6.5 \pm 2.14 \mathrm{mms}$. This is in accordance with the study of Dellabella et al. who had an average stone size of $6.7 \mathrm{~mm}$. There was no difference in the stone expulsion rates for right (83\%) and left (72\%) ureteric stones in our study (P value $=0.31)$.

\section{Conclusion}

Medical therapy with a combination of $\alpha_{1}$ adrenergic blocker and corticosteroid is associated with good stone 
expulsion rates and should be considered in all patients with lower ureteral stones of size less than $10 \mathrm{~mm}$ who are not having any contraindications for medical therapy.

\section{References}

[1] Moe, O.W. (2006) Kidney Stones: Pathophysiology and Medical Management. The Lancet, 367, 333-344. http://dx.doi.org/10.1016/S0140-6736(06)68071-9

[2] Grasso, M., Conlin, M. and Bagley, D. (1998) Retrograde Ureteropyeloscopic Treatment of 2 cm or Greater Upper Urinary Tract and Minor Staghorn Calculi. The Journal of Urology, 160, 346-351. http://dx.doi.org/10.1016/S0022-5347(01)62892-1

[3] Segura, J.W., Preminger, G.M., Assimos, D.G., Dretler, S.P., Kahn, R.I., Lingeman, J.E., et al. (1997) Ureteral Stones Clinical Guidelines Panel Summary Report on the Management of Ureteral Calculi. The American Urological Association. The Journal of Urology, 158, 1915-1921. http://dx.doi.org/10.1016/S0022-5347(01)64173-9

[4] Coll, D.M., Varanelli, M.J. and Smith, R.C. (2002) Relationship of Spontaneous Passage of Ureteral Calculi to Stone Size and Location as Revealed by Unenhanced Helical CT. American Journal of Roentgenology, 178, 101-103. http://dx.doi.org/10.2214/ajr.178.1.1780101

[5] Roberts, W.W., Cadeddu, J.A., Micali, S., Kavoussi, L.R. and Moore, R.G. (1998) Ureteral Stricture Formation after Removal of Impacted Calculi. The Journal of Urology, 159, 723-726. http://dx.doi.org/10.1016/S0022-5347(01)63711-X

[6] Dellabella, M., Milanese, G. and Muzzonigro, G. (2003) Efficacy of Tamsulosin in the Medical Management of Juxtavesical Ureteral Stones. The Journal of Urology, 170, 2202-2205. http://dx.doi.org/10.1097/01.ju.0000096050.22281.a7

[7] Porpiglia, F., Destefanis, P., Fiori, C. and Fontana, D. (2000) Effectiveness of Nifedipine and Deflazacort in the Management of Distal Ureter Stones. Urology, 56, 579-582. http://dx.doi.org/10.1016/S0090-4295(00)00732-9

[8] Hussain, Z., Inman, R.D., Elves, A.W., Shipstone, D.P., Ghiblawi, S. and Coppinger, S.W. (2001) Use of Glyceryil Trinitrate Patchesin Patients with Ureteral Stones: A Randomized, Double-Blind, Placebo-Controlled Study. Urology, 58, 521-525. http://dx.doi.org/10.1016/S0090-4295(01)01323-1

[9] Porpiglia, F., Ghignone, G., Fiori, C., Fontana, D. and Scarpa, R.M. (2004) Nifedipine versus Tamsulosin for the Management of Lower Ureteral Stones. The Journal of Urology, 172, 568-571. http://dx.doi.org/10.1097/01.ju.0000132390.61756.ff

[10] Cervenakov, I., Fillo, J., Mardiak, J., Kopecny, M., Smirala, J. and Lepies, P. (2002) Speedy Elimination of Ureterolithiasis in Lower Part of Ureters with the Alpha 1 Blockers-Tamsulosin. International Urology and Nephrology, 34, 25-29. http://dx.doi.org/10.1023/A:1021368325512

[11] Segura, J.W., Preminger, G.M., Assimos, D.G., Dretler, S.P., Kahn, R.I., Lingeman Jr., J.E., et al. (1997) Ureteral Stones Clinical Guidelines Panel Summary Report on the Management of Ureteral Calculi. The Journal of Urology, 158, 1915-1921. http://dx.doi.org/10.1016/S0022-5347(01)64173-9

[12] Menon, M., Parulkar, B.G. and Drach, G.W. (1998) Urinary Lithiasis: Etiology, Diagnosis and Medical Management. In: Walsh, P.C., Retik, A.B., Vaughan Jr., E.D. and Wein, A.J., Eds., Campbell's Urology, 7th Edition, W. B. Saunders Co., Philadelphia, Vol. 3, p. 2702.

[13] Malin Jr., J.M., Deane, R.F. and Boyarsky, S. (1970) Characterisation of Adrenergic Receptors in Human Ureter. British Journal of Urology, 42, 171-174. http://dx.doi.org/10.1111/j.1464-410X.1970.tb10018.x

[14] Tekin, A., Aklan, E., Beysel, M., Yucebas, E., Aslan, R. and Sengor, F. (2004) Alpha-1 Receptor Blocking Therapy for Lower Ureteral Stones: A Randomized Prospective Trial. The Journal of Urology, 171, 304, abstract 1152. 